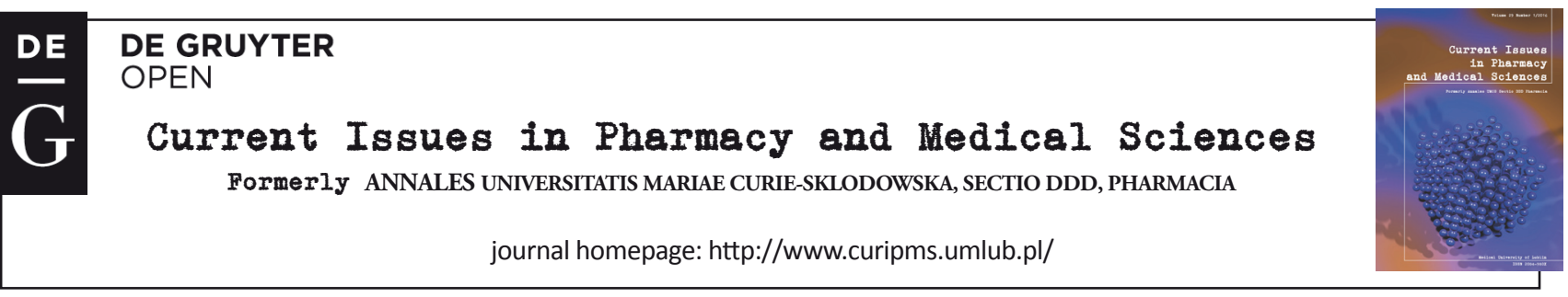

\title{
Furochinoline alkaloids in plants from Rutaceae family - a review
}

\author{
Aldona Adamska-SzewCZYK ${ }^{1 *}$, Kazimierz GlowniaK ${ }^{2}$, Tomasz BaJ ${ }^{2}$
}

${ }^{1}$ Hibiscus Pharmacy, 26 Puławska Str, 02-512 Warszawa, Poland

${ }^{2}$ Department Pharmacognosy with Medical Plant Unit, Medical University of Lublin, 1 Chodzki , 20-093 Lublin, Poland

\begin{tabular}{|c|c|}
\hline ARTICLE INFO & ABSTRACT \\
\hline $\begin{array}{l}\text { Received } 17 \text { November } 2015 \\
\text { Accepted } 11 \text { January } 2016\end{array}$ & $\begin{array}{l}\text { Over the past five years, phytochemical and pharmacological studies have been } \\
\text { conducted on material extracted from members of the Rutaceae family. In such work, }\end{array}$ \\
\hline $\begin{array}{l}\text { Keywords: } \\
\text { Rutaceae, } \\
\text { furochinoline alkaloids, } \\
\text { dictamnine, } \\
\text { skimmianine, } \\
\text { kokusaginine, } \\
\text { activity, } \\
\text { Zanthoxylum, } \\
\text { Evodia, } \\
\text { Conchocarpus, } \\
\text { Myrthopsis, } \\
\text { Teclea. }\end{array}$ & $\begin{array}{l}\text { new furochinoline-structured alkaloids were isolated from Ruta sp. and Dictamnus sp. } \\
\text { Beyond the aforementioned, other substances with promising activity were isolated } \\
\text { from the less-known species of Zanthoxylum, Evodia, Lonchocarpus, Myrthopsis and } \\
\text { Teclea. Currently used forms of extraction, as well as methods of isolation and detection, } \\
\text { allow the obtaining of pure, biologically active compounds. Many of these have anti- } \\
\text { fungal, anti-bacterial and anti-plasmodial properties. Others are still being researched as } \\
\text { potential drugs, which, in future, may be used in treating those afflicted with HIV and } \\
\text { cancer. This article is designed to give the readers a thorough review of the active natural } \\
\text { products from the Rutaceae family. }\end{array}$ \\
\hline
\end{tabular}

\section{INTRODUCTION}

The Rutaceae family has about 140 genera [6], consisting of herbs, shrubs and small trees which grow in all parts of the world [28,29,38], and which are used in traditional medicine for treating snake bites, stomatitis, rheumatism, bronchitis and other diseases [28]. This plant family is the source of furanocoumarines, furochinoline alkaloids, phenolic-structured compounds, terpens and other substances $[12,25,27]$. The main alkaloid compounds drawn from this family are dictamnine (1), skimmianine (2) and kokusaginine (13). In pharmacy, the most-known species of Rutaceae family are Ruta graveolens L. and Ruta montana Mill. The latter plant, and the substances isolated from it, were subject to Nuclear Magnetic Resonance (NMR) research by Vasudevan \& Luckner, in 1968 [33]. From the whole plant, they extracted and examined six alkaloids: 2-(nonan-8-one)-(1H)-4-quinolone, 2-(nonan-8-one)-4methoxy-quinoline, 2-(nonan-8-one)-N-methyl-4-quinolone, 2-(decan-9-one)-N-methyl-4-quinolone, evolitrine (6) and 1-methyl-4-methoxy-2-quinolone [32]. The most thoroughly examined compound is dictamnine (1). This is the first alkaloid isolated from this plant. In 1967, Moncović et al. [21] presented the biosynthesis of dictamnine in Dictamnus albus L. These researchers examined this substance via the tracer method, and determined the quinoline nucleus from acetate and from anthranilic acid. Between 2010 and 2015, further studies have been conducted which revealed new alkaloid substances with the furochinoline structure. These alkaloids are a group of substances characteristic for the Rutaceae family (Fig. 1).<smiles>[R]c1ccc2c(OC)c3ccoc3nc2c1[R]</smiles>

\begin{tabular}{|c|c|c|c|}
\hline No. & Compound & $\mathrm{R}_{1}$ & $\mathrm{R}_{2}$ \\
\hline 1 & Dictamnine & $-\mathrm{H}$ & $-\mathrm{H}$ \\
\hline 2 & Skimmianine & $-\mathrm{OCH}_{3}$ & $-\mathrm{OCH}_{3}$ \\
\hline 3 & Y-Fagarine & $\mathrm{H}$ & $-\mathrm{OCH}_{3}$ \\
\hline 4 & Haplopine & $-\mathrm{OH}$ & $-\mathrm{OCH}_{3}$ \\
\hline 5 & 7-hydroxydictamnine & $-\mathrm{OH}$ & $-\mathrm{H}$ \\
\hline 6 & Evolitrine & $-\mathrm{OCH}_{3}$ & $-\mathrm{H}$ \\
\hline
\end{tabular}

\footnotetext{
* Corresponding author

e-mail: a.adamskaszewczyk@gmail.com
} 
<smiles>[R]c1cc([R2])c2c(c1)c(=O)c1ccoc1n2C</smiles>

\begin{tabular}{|c|c|c|c|}
\hline No & Compound & $\mathrm{R} 1$ & $\mathrm{R} 2$ \\
\hline 7 & Isodictamnine & $-\mathrm{H}$ & $-\mathrm{H}$ \\
\hline 8 & Isomaculosidine & $-\mathrm{OCH}_{3}$ & $-\mathrm{OCH}_{3}$ \\
\hline 9 & Iso- - -fagarine & $-\mathrm{H}$ & $-\mathrm{OCH}_{3}$ \\
\hline 10 & Dictangustine- $\mathrm{A}$ & $-\mathrm{OH}$ & $-\mathrm{H}$ \\
\hline 11 & Isopteleine & $-\mathrm{OCH}_{3}$ & $-\mathrm{H}$ \\
\hline
\end{tabular}

Figure 1. The structures of the main furoquinoline alkaloids isolated from plants of the Rutaceae family

\section{Extraction of furoquinoline alkaloids from Rutaceae family plants}

Sandjo et al. [28] isolated furoquinoline alkaloids from Zanthoxylum buesgenii (Engl.) P.G.Waterman, using Dragendorff's method. In this work, dried aerial plant material was first cut into small pieces, then crushed, and the powder underwent extraction for two days, using methylene chloride $(\mathrm{DCM}) / \mathrm{MeOH}(1: 1 \mathrm{v} / \mathrm{v})$. The solid residue was subsequently extracted with $\mathrm{MeOH}$. After 24 hours, both solutions were mixed and then evaporated under reduced pressure in vacuo. A crude extract was thus obtained, which was then subjected to a liquid-solid extraction using $\mathrm{N}$-hexane (HEX), ethyl acetate (EA) and $\mathrm{MeOH}$ (the liquid part). Both fractions were combined based on a thin-layer chromatography (TLC) profile, to give fraction A. Fractions $\mathrm{A}$ and $\mathrm{B}(\mathrm{MeOH})$ were then reacted with Dragendorff's reagent, which indicated the presence of alkaloids in fraction A. This fraction (A) was then separated out by the silica gel $\mathrm{CC}$ method. Elution was next conducted with the use of HEX, HEX/EA (gradient) and EA, yielding six sub-fractions. Herein, maculine (12) was obtained. In further extractions, isofagaridine, kokusaginine (13) and teclearverdoornine (14) were collected, and examined via NMR. The compounds isolated from aerial part of $Z$. buesgenii are shown in Fig. 2 [28]:<smiles>COc1c2cc3c(cc2nc2occc12)OCO3</smiles><smiles>COc1cc2nc3occc3c(OC)c2cc1OC</smiles>
maculine (12)<smiles>COc1c2ccoc2nc2c(O)c3c(c(CC=C(C)C)c12)OCO3</smiles>

kokusaginine (13)

teclearverdoornine (14)

Figure 2. The furoquinoline alkaloids isolated from the aerial parts of Zanthoxylum buesgenii (Rutaceae) [28]
Another approach to alkaloid extraction was presented by Resmi et al., in the investigation of a type III polyketide synthase involved in the quinolone alkaloid biosynthesis of material obtained from Aegle marmelos (L.) Correa. This work was the first report of a gene being involved in quinolone biosynthesis as seen in plant material. Quinolone synthase, which is a type III polyketide synthase, was shown to synthesize diketide 4-hydroxy-1-methyl-2H-quinolone, by utilizing a unique substrate binding site [26].

Sichaem et al. [29], while conducting pharmacognostic studies of new substances in the leaves of Evodia lepta (Spreng.) Merr., isolated 3 leptanoines A-C (15-17), melineurine (18), dictamnine (1) and 7-hydroxydictamnine (5). In their work, the dried leaves of the plant underwent extraction twice with 5 liters of methanol, at room temperature. The result was then subjected to evaporation, supra, VLC (vacuum-liquid chromatography) and silica gel chromatography. The subsequent elution process was completed by the use of solvents of increasing polarity in the following order: dichloromethane, ethyl acetate and methanol. Four fractions were obtained, of which, one was subjected to column chromatography with dichloromethane, yielding several sub-fractions. One of these was purified with chromatotron under the same conditions; another was dealt with by way of utilizing dichloromethane with an ethyl acetate relative: 1:0 and 0:1 $\mathrm{v} / \mathrm{v}$. The obtained compounds were characterized via several spectroscopic methods (NMR, MS, IR, UV). The structures of the isolated alkaloids from the E. lepta are shown in Fig. 3 [29]:<smiles>[R]c1cc2c(OC)c3ccoc3nc2c([R])c1O/C=C\C(=C)C</smiles>

\begin{tabular}{|c|c|c|c|}
\hline No & Compound & R1 & R2 \\
\hline 15 & Leptanoine A & $-\mathrm{H}$ & $-\mathrm{H}$ \\
\hline 16 & Leptanoine B & $-\mathrm{OCH}_{3}$ & $-\mathrm{H}$ \\
\hline
\end{tabular}<smiles>[R]c1cc2c(OC)c3ccoc3nc2c([R])c1OCC=C(C)C</smiles>

\begin{tabular}{|c|c|c|c|}
\hline No & Compound & $\mathrm{R} 1$ & $\mathrm{R} 2$ \\
\hline 16 & Leptanoine $\mathrm{C}$ & $-\mathrm{OCH}_{3}$ & $-\mathrm{H}$ \\
\hline 17 & Melineurine & $-\mathrm{H}$ & $-\mathrm{H}$ \\
\hline
\end{tabular}

Fig. 3. The structures of the furoquinoline alkaloids isolated from the leafy material of Evodia lepta (Spreng.) Merr.

Cabral et al. [6] utilized stem material of Conchocarpus fontanesianus (A. St.-Hill.) Kallunki\&Pirani. in their work. The extraction involved powdered material and ethanol, using an extractor under pressure at a temperature of $60^{\circ} \mathrm{C}$. The solution was then thickened in vacuum. Next, the extract was dissolved in $0.1 \mathrm{M} \mathrm{HCl}$, filtered and partitioned with hexane. The acid aqueous fraction was subsequently treated with $\mathrm{NH}_{4} \mathrm{OH}$ and $\mathrm{CHCl}_{3}$. The alkaloid fraction was 
then obtained, and TLC analysis was completed using $\mathrm{CHCl}_{3}: \mathrm{MeOH}: \mathrm{NH}_{4} \mathrm{OH}(90: 7.5: 2.5 \mathrm{v} / \mathrm{v})$ as the eluent. This alkaloid fraction was also analyzed via HPLC. In this work, in the stem material, the presence of dictamnine (1), skimmianine (2), $\gamma$-fagarine (3), 2-phenyl-1-methyl-quinoline and marmesine was confirmed [6].

Tchinda et al. [31] investigated the bioactivity of dried Zanthoxylum leprieurii (Guill. \& Perr.) Engl. fruit. The fruits, after blending, underwent extraction with ethyl acetate. The concentrated extracts were subjected to column chromatography (CC) with silica gel, and then eluted with EtOAc in petroleum ether. The fractions were subsequently collected and characterized by TLC. One of these was additionally chromatographed over $\mathrm{CC}$, in petroleum ether using EtOAc at 80:20-75:35 v/v. The following compounds were isolated: 1-hydroxy-3,4-dimethoxy-N-methylacridone, tegerrardin A, arborinine, scoparone and xanthotoxoline. The structural analysis of the compounds was completed by mass spectra and $1 \mathrm{H}$ and C13 NMR. The above-mentioned substances were assessed as coumarins and alkaloids, but not furoquinolines [31].

Mora et al. [22] researched the chemical components of Zanthoxylum setulosum (P. Wilson). In their work, dried aerial parts of the plant underwent extraction with methyltert-butyl-ether (MTBE): methanol $(\mathrm{MeOH})$ 9:1 v/v, for one day. Next, the solvent was removed under reduced pressure and $\mathrm{CHCl}_{3}$ was added. To identify the substances in the extracts, they employed CC (silica gel) in an elution gradient, using hexane: MTBE $(85: 15-0: 100 \mathrm{v} / \mathrm{v})$ and MTBE:MeOH (90:10-80:20). In this work, the researchers obtained 7 fractions. For the isolation of the alkaloids, they carried out preparative TLC, eluting with benzene and $\mathrm{CH}_{2} \mathrm{Cl}_{2}(1: 1 \mathrm{v} / \mathrm{v})$ and benzene: $\mathrm{CH}_{2} \mathrm{Cl}_{2}: \operatorname{MTBE}(4: 4: 2 \mathrm{v} / \mathrm{v})$. Next, the extract was subjected to $1 \mathrm{H}$ and $13 \mathrm{C}$ NMR, as well as COSY (Co-relation Spectroscopy), HMQC (Heteronuclear Multiple Quantum Coherence) and HMBC (Heteronuclear Multiple Bond Coherence) [22], leading to the identification of skimmianine (2).

Gaya et al. [16] set out to identify the substances that could be found in the roots, bark and leaves of the Kenyan Zanthoxylum gilletii (De Wild.) P.G.Waterman. In this work, the powdered raw material was extracted with menthol for three days, and the extract was then analyzed by TLC, HPLC and LC-MS. In the thin layer chromatography, they used silica gel plates and papaverine chloride in methanol as standard. The TLC-UV spectra was observed under an UV spectrophotometer (254-366 nm), and the $\mathrm{R}_{\mathrm{f}}$ (the retention factor) was recorded after the extract was sprayed with Dragendorff's reagent. TLC and LC-MS analyses were then used to test the presence of alkaloids. Via this work, the following compounds have been identified: peroxysimulenoline, sanguinarine, fagarine I, norchelerythrine, trans-fagaramide, 8-ethylnorchelerythrine and dihydronitidine [16].

Magadula et al. described the substances isolated from several plant families indigenous to Tanzania. In this work, they discovered that the stem material of Teclea amaniensis Engl. contained six furoquinoline alkaloids: tecleamaniensine A (18), tecleamaniensine B (19), amaniensine, dictamnine (1), kokusaginine (13) and evoxanthine. The researchers also demonstrated the biological activity of these substances on the larvae of Culex quinquefascintus [19]. The structure of tecleamaniensine $\mathrm{A}$ and tecleamaniensine $\mathrm{B}$ are presented in Fig. 4.<smiles>COc1cc2nc3occc3c(OC)c2c(CC=C(C)C)c1OC</smiles>
tecleamaniensine $A(18)$<smiles>COc1cc2nc3occc3c(OC)c2c(O)c1CC1OC1(C)C</smiles>

tecleamaniensine B (19)

Figure 4. The structures of tecleamaniensine A and tecleamaniensine B isolated from Teclea amaniensis Engl.

Mwangi et al. [24] researched by chromatographic separation, substances found in the leaves of Teclea trichocarpa (Engl.) Engl. To accomplish this, the authors utilized a mixture of $n$-hexane, methanol and dichloromethane and extracted the plant material three times at room temperature. A dichloromethane extract was followed by TLC and $\mathrm{CC}$, after preparative TLC was initiated with hexane and dichloromethane. Following the application of IR, $1 \mathrm{H}$ and 13C NMR, they obtained the structures of the following alkaloids: skimmianine (2), melicopicine, normelicopicine and arborinine (acridone alkaloids).

In addition to the previous, Coulerie et al. isolated skimmianine (2), $\gamma$-fagarine (3) and haplopine (4) [9] from the bark and leaves of Myrtopsis corymbosa (Labill.) Guillaumin. In so doing, crude extracts of ethyl acetate were processed by automated solvent extraction systems (ASE).

\section{The biological activity of furoquinoline alkaloids}

Rutaceae-derived substances obtained from, for example, the roots and bark of Dictamnus dasycarpus Turcz. possess very interesting biological activities that have been long utilized in folk medicine. In traditional Chinese medicine, D. dasycarpus Turcz. derivatives are used in the treatment of rheumatism, jaundice, skin diseases and cough [10].

In a study conducted by Basco et al. [4], in 1994, the in vitro activities against Plasmodium falciparum and Leischmania spp. of the furoquinoline alkaloids: skimmianine (2), haplopine (4), kokusaginine (13), acronydine (20) and acronycidine (21), isolated from Geijera balansae (Baill.) Schinz \& Guillaumin, Sarcomelicope glauca T.G. Hartley, and Sarcomelicope dogniensis T.G. Hartley, were noted. Similar results were obtained by Fournet et al. [15]. The structures of acronydine and acronycidine can be seen in Fig. 5:<smiles>COc1cc2nc3occc3c(OC)c2c2c1OC(C)(C)C=C2</smiles>

acronydine (20) 


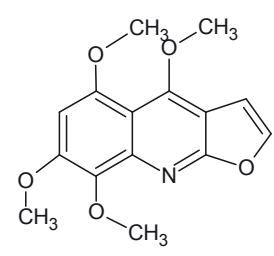

\section{acronycidine (21)}

Figure 5. The structures of acronydine and acronycidine isolated from Teclea amaniensis Engl.

Furthermore, dictamnine (1), which was isolated from D. dasycarpus Turcz., has been found to possess anti-fungal properties [35]. Zhao et al. [39,40] demonstrated this activity against the plant pathogenic fungus Cladosporium cucumerinum in tests conducted on TLC plates. They also conducted pharmacological research on the use of a dichloromethane extract containing dictamnine (1) and limonoid. This alkaloid is toxic, but derivatives have been shown to have anti-cancer properties, against the growth of certain solid cancer cells, among these being non-small cell lung cancer, breast cancer and CNS cancer.

Moreover, in a study undertaken by Emam et al. [13], a new furoquinoline alkaloid: 5-(1,1-dimethylallyl)-8hydroxyfuro[2-3-b]quinoline (22) derived from Ruta chalepensis L., has also been shown to have anti-fungal activity. In their work, chloroform extracts isolated from the leaves of this species were active against the following fungi: Fusarium solani, Sclerotium rolfsii and Rhizoctonia solani. These fungi have negative effects on potatoes, tomatoes and sugar beets [13]. In another study, the efficacy of methanolic extracts of Ruta chalepensis $\mathrm{L}$. and the aerial parts of other related species was evaluated against Culex pipiens larvae [1]. The researcher concluded that substances naturally found in Ruta chalepensis L. were effective against these larvae, and they pose little or no animal and human risk. The structure of 5-(1,1-dimethylallyl)-8-hydroxyfuro[23-b]quinolone, a new furoquinolone alkaloid isolated from Ruta chalepensis L. can be seen in Fig. 6:

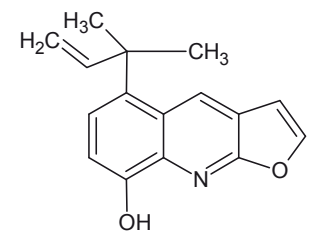

5-(1,1-dimethylallyl)-8-hydroxyfuro[2-3-b]quinolone (22)

Figure 6. The structure of 5-(1,1-dimethylallyl)-8-hydroxyfuro[23-b]quinolone, a new furoquinolone alkaloid isolated from Ruta chalepensis L.

Wahyunia et al. isolated six compounds from Ruta angustifolia Pers. leaves: chalepin, scopoletin, $\gamma$-fagarine (3), kokusaginine (13), arborinine, and pseudane IX, and observed antiviral activities against HCV in cell cultures. They noted that chalepin and pseudane IX had strong anti-HCV activity without cytotoxity. What is more, these compounds were more active than ribavirin, the standard used in treatment. The $\mathrm{IC}_{50}$ of $\gamma$-fagarine (3) was $20.4 \mu \mathrm{g} / \mathrm{ml}$, but it was $2.8 \mu \mathrm{g} / \mathrm{ml}$ for ribavirin and $6.4 \mu \mathrm{g} / \mathrm{ml}$ for kokusaginine (13) [34].
Sandjo et al. [28] researched the cytotoxicity of the aerial parts of Zanthoxylum buesgenii (Engl.) P.G.Waterman. In this work, doxorubicin was used as a control drug, and the activities of the isolated compounds: isofagaridine, maculine, kokusaginine (13), tecleaverdoornine (14) and buegenine, were observed on the tested cancer cell lines, towards leukemia CCRF-CEM and CEM/ADR5000, breast cancer MDA-MB231 and its resistant sub-line MDAMB231/BCRP, colon cancer HCT116p53 $3^{++}$and its resistant sub-line HCT116p53--, glioblastoma U87MG, hepatocarcinoma $\triangle$ EGFR and HepG2. Herein, isofagaridine, kokusaginine (13) and masculine were shown to be more active than doxorubicin [28].

In 2013, Tavares et al. [30] researched the anti-microbial activity of alkaloids obtained from Zanthoxylum rhoifolium Lam. In this work, it was demonstrated that methanol extracts, obtained by initially steaming bark tissues, exhibited a broad spectrum of antimicrobial activity. In the study, three alkaloids were isolated: skimmianine (2), $\gamma$-fagarine (3) and isohaplopine (23). These compounds were tested against the following microorganisms: seven Gram $(+)$ bacteria: Bacillus subtilis, B. cereus, Staphylococcus aureus, S. epidermidis, Streptococcus pyogenes, Enterobacter aerogenes, Enterococcus spp; eight Gram(-) bacteria: Escherichia coli, Klebsiella pneumonia, Pseudomonas aeruginosa, Enterobacter cloacae, Shigella sonnei, Salmonella typhimurium, Burkholderia cepacia, Morganella morganii and Candida albicans, C. tropicali, C. krusei, C. parapslosis, Sacharomyces cerevisae, Cryptococcus neoformans and C. gatti [30].

Leptanoines and other furochinoline alkaloids have also been obtained from the leaves of Evodia lepta (Spreng.) Merr. [29]. In this study, the inhibitory activity against acetylcholinesterase (AChE) and butyrylcholinesterase (BChE) was researched, with galanthamine being used as standard. This work showed that leptanoine A, leptanoine B, leptanoine $\mathrm{C}$ and 7-hydroxydictamnine were the most active. The leptanoines were particularly noted as demonstrating the strongest effect. Regarding $\mathrm{AChE}$, the $\mathrm{IC}_{50}(\mu \mathrm{M})$ of the leptanoines was more than $200 \mu \mathrm{M}$, in comparison with $5.6 \mu \mathrm{M}$ for galantamine. Melineurine showed the highest inhibitory activity towards $\mathrm{BChE}$ ( $\mathrm{an}_{\mathrm{IC}}$ value of $47.9 \mu \mathrm{M}$ ), whereas skimmianine (2) had the highest inhibitory activity towards AChE (an $\mathrm{IC}_{50}$ value of $69.1 \mu \mathrm{M}$ ). It should be noted that the inhibitory activity of these compounds could be potentially used in the future to treat Alzheimer's disease [29].

In addition to the afore-mentioned, kokusaginine (13) and skimmianine (2) were isolated from Evodia merrilli Kanehira\&Sasaki. These compounds were shown to inhibit 5-HT2 receptor activity. The results obtained suggest that these alkaloids could have significance in the treatment of various diseases related to serotonin neurotransmission, for example, depression [8].

Biavatti et al. [5] note that certain compounds obtained from Raulinoa echinata R.S.Cowan. have similar properties. In their work, they isolated skimmianine (2), maculine (12), kokusaginine (13) and flindersiamine (24) from stem and leaf tissues. They also found the quinolone derivatives: 
1-methyl-2-n-nonyl-4-quinolone, 2-n-nonyl-4-quinolone and 1-methyl-2-phenyl-4-quinolone.

Moreover, they observed biological activity against Leucoagaricus gongylophorus, a fungus found on the Atta sexdens leaf, and each of the alkaloids were demonstrated to inhibit the growth of L. gongyphorus, when compared with the original extracts. In addition, through in vitro study, the activity of quinolinone alkaloids was shown against a form of Trypanosoma cruzi, Leishmania spp and Plasmodium falciparum [5]. The structures of isohaplopine and flindersiamine are compared in Fig 7.<smiles>COc1ccc2c(OC)c3ccoc3nc2c1O</smiles>

isohaplopine (23)<smiles></smiles>

flindersiamine (24)

Figure 7. The structures of isohaplopine and flindersiamine compared

The alkaloids that have been isolated from the stems of Conchocarpus fontanesianus (A. St.-Hill.) Kallunki\&Pirani, by Cabral et al. [6], have been shown to have inhibitory activity towards acetyl cholinesterase. In this study, skimmianine (2) was shown to be more active. It should be noted that some of the substances from Brazilian vegetal species are used in the treatment of Alzheimer's disease, although they have low bioavailability and show hepatotoxicity.

In other work, Cardoso-Lopes et al. [7] isolated certain alkaloids from Esenbeckia leiocarpa Engl. In the obtained extracts, the authors identified: leiokinine A, leptomerine, kokusaginine (13), skimmianine (2), maculine (12) and flindersiamine (24). In their study, leptomerine showed the highest inhibitory activity towards AChE. This was similar to that of the reference compound, galanthamine. The results of their work reveal that the alkaloids eptomerine and skimmianine (2) have potent anticholinesterasic activity.

Mwangi et al. [24] tested a methanolic crude extract, as well as six compounds isolated from the leaves of Teclea trichocarpa (Engler) Engl. in vitro against Plasmodium falciparum, Trypanosoma cruzi, T. brucei rhodesience and Leishmania donovani. In such work, skimmianine (2) showed weak activity against $L$. donovani, $P$. falciparum, strong activity against $T$. cruzi and $T$. brucei, and exhibited cytotoxicity towards L-6 cells with a minimum inhibitory concentration (MIC) of $38.6 \mu \mathrm{g} / \mathrm{ml}$. This study has shown that furoquinoline alkaloids are potential anti-protozoal compounds [24].

In addition, An Huang et al. [17] synthesized and researched substances with the furochinoline alkaloid structure: 2,3,4,9-tetrahydrofuro[2,3-b]quinolin-3,4-dione and ethyl 2-(substituted aniline)-4-oxo-4,5-dihydrofuran -3-carboxylate. The intent of such work was to ascertain the relationships between structure and cytotoxicity on murine leukemia WEHI-3 cells.

Table 1 lists the biological properties of some of the alkaloids present in the Rutaceae family:

Table 1. The activity of various furochinoline alkaloids that have been isolated from the Rutaceae family

\begin{tabular}{|c|c|c|c|}
\hline Substances & Source & Activity & Ref. \\
\hline Skimmianine & $\begin{array}{c}\text { Galipea longiflora } \\
\text { Krause }\end{array}$ & \multirow{2}{*}{$\begin{array}{c}\text { Leishmaniosa/ } \\
\text { Anticholinesterasic }\end{array}$} & \multirow{2}{*}[14,15,23]{} \\
\hline Kokusaginine & $\begin{array}{c}\text { Galipea longiflora } \\
\text { Krause }\end{array}$ & & \\
\hline Maculine & $\begin{array}{c}\text { Esenbeckia } \\
\text { leiocarpia Eng. } \\
\text { Teclea afzelii Eng. }\end{array}$ & \multirow{4}{*}{ Antiplasmodial } & \multirow{4}{*}[3,11,23,36]{} \\
\hline Tecleaverdoornine & $\begin{array}{l}\text { Teclea verdoorniana } \\
\text { Exell \& Mendonça }\end{array}$ & & \\
\hline Y-Fagarine & $\begin{array}{c}\text { Esenbeckia febrifuga } \\
\text { (A. St.-Hil.) A. Juss. } \\
\text { ex Mar. }\end{array}$ & & \\
\hline Dictamnine & $\begin{array}{c}\text { Esenbeckia febrifuga } \\
\text { (A. St.-Hil.) A. Juss. } \\
\text { ex Mar. }\end{array}$ & & \\
\hline Flindersiamine & $\begin{array}{c}\text { Esenbeckia } \\
\text { yaaxhokob Lundell }\end{array}$ & \multirow{3}{*}{ Antibacterial } & \multirow{3}{*}[2,5,18,20,23]{} \\
\hline Pteleatine & Ptelea trifoliate L. & & \\
\hline Kolbisine & Teclea afzelii Eng. & & \\
\hline Dictamnine & $\begin{array}{c}\text { Esenbeckia febrifuga } \\
\text { (A. St.-Hil.) A. Juss. } \\
\text { ex Mar. }\end{array}$ & \multirow{3}{*}{ Antifungal } & \multirow{3}{*}[11,18,23,39]{} \\
\hline Haplopine & $\begin{array}{c}\text { Dictamnus } \\
\text { dasycarpus Turcz. }\end{array}$ & & \\
\hline Kolbisine & Teclea afzelii Eng. & & \\
\hline
\end{tabular}

\section{CONCLUSIONS}

The Rutaceae family is a potential source of many medicinal substances. Extensive work carried by many research centers shows the potential application of these natural products in the treatment of such diverse conditions as Alzheimer's disease and depression, as well as in treating cancer and infections. This is due to their anti-bacterial, anti-fungal, anti-leishmanial and anti-plasmodial properties. New methods for isolating compounds from plant material, as well as methods of testing their structures, encourage further exploration of their biologically active substances.

\section{REFERENCES}

1. Abdel-Sattar E., Zaitoon A., El Sayed A.M., Bakhashwain A.A.: Evaluation of some Medicinal plants in controlling Culex pipienis, J. Egypt. Soc. Parasitol., 44(3), 771-778, 2014.

2. Aguilar-Guadarrama A.B., Rios M.Y.: Geranyl n-dimethylallylanthranilate, a new compound from Esenbeckia yaaxhokob, Planta Medica, 70(1), 85-86, 2004.

3. Almeida R., Penaflor M. et al.: Toxicity of substances isolated from Helietta puberula RE Fr. (Rutaceae) to the leaf-cutting ant Atta sexdens L. (Hymenoptera: Formicidae) and the symbiotic fungus Leucoagaricus gongylophorus. BioAssay, 2(2), 1-8, 2007.

4. Basco, L.K., Mitaku, S. et al.: In vitro activities of furoquinoline and acridone alkaloids against Plasmodium falciparum. Antimicrob. Agents Chemother., 38(5), 1169-1171, 1994.

5. Biavatti, M.W., Vieira, P.C. et al.: Biological Activity of Quinoline Alkaloids from Raulinoa echinata and X-ray Structure of Flindersiamine, J. Braz. Chem. Soc., 13 (1), 66-70, 2002.

6. Cabral R.S., Sartori M.C. et al.: Anticholinesterase activity evaluation of alkaloids and coumarin from the stems of Conchocarpus fontanesianus, Braz. J. Pharmacogn. 22(2), 374-380, 2012.

7. Cardoso-Lopes E.M., Maier J.A., da Silva M.R. et al.: Alkaloids from stems of Esenbeckia leiocarpa Engl. (Rutaceae) as potential treatment for Alzheimer disease. Molecules, 15 (12), 9205-9213, 2010. 
8. Cheng J.T., Chang T.K., Chen I.S.: Skimmianine and related furoquinolines function as antagonists of 5-hydroxytryptamine receptors in animals, J. Auton. Pharm., 14, 365-374, 1994.

9. Coulerie P., Maciuk A. et al.: Phytochemical study of Myrtopsis corymbosa, perspectives for anti-dengue natural compound research, Rec. Nat. Prod., 7(3), 250-253, 2013.

10. Dictionary of Chinese Traditional Medicine. Shanhai Science and Technology Press, 1986, Shanghai, Jiansu New Medical College p. 737

11. Dolabela M.F., Oliveira S.G. et al.: In vitro antiplasmodial activity of extract and constituents from Esenbeckia febrifuga, a plant traditionally used to treat malaria in the Brazilian Amazon, Phytomed.: Int. J. Phytother. Phytopharm., 15(5), 367-372, 2008.

12. Ekiert H., Kisiel W.: Coumarins and alkaloids in shoot culture of Ruta graveolens L. Acta Soc. Bot. Polon., 66(3-4), 329-332, 1997.

13. Emam A., Eweis M., Elbadry M.: A new furoquinoline alkaloid with antifungal activity from the leaves of Ruta chalepensis L., Drug Disc. Ther., 4(6), 399-404, 2010.

14. Fournet A., Barrios A.A. et al.: Antiprotozoal activity of quinoline alkaloids isolated from Galipea longiflora, a Bolivian plant used as a treatment for cutaneous leishmaniasis, Phytother. Res., 8(3), 174-178, 1994.

15. Fournet A., Barrios A.A. et al.: 2-substituted quinoline alkaloids as potential antileishmanial drugs., Antimicrob. Agents Chemother., 37(4), 859-863, 1993.

16. Gaya C. H., Kawaka J.F., Muchugi A., Ngeranwa J. J.: Variation of alkaloids in the Kenyan Zanthoxylum gilletii (De Wild Waterman), Afr. J. Plant Sci., 7(9), 438-444, 2013.

17. Huang A.C., Chung J.G. et al.: Synthesis and cytotoxic activity of certain 2,3,4,9-Tetrahydrofuro[2,3-b]quinolin-3,4-dione and ethyl 2-(Substituted aniline)-4-oxo-4,5-dihydrofuran-3-carboxylate derivatives in Murine leukemia WEHI-3 Cells. In Vivo. 21(2), 227-236, 2007.

18. Kuete V., Wansi J.D. et al.: Antimicrobial activity of the methanolic extract and compounds from Teclea afzelii (Rutaceae), South Afr. J. Bot., 74(4), 572-576, 2008.

19. Magadula J.J., Innocent E., Mbwambo Z.H., Kapingu M.C.: Phytochemical and Pharmacological Studies of some Medicinal Plants from Tanzania. Int. J. Curr. Res. Acad. Rev., 2(10), 99-111, 2014.

20. Mitscher L.A., Bathala M.S., Clark G.W., Beal J.L.: Antimicrobial agents from higher plants. The quaternary alkaloids of Ptelea trifoliate. Lloydia, 38(2), 109-116, 1975.

21. Monković I., Spenser I.D., Plunkett A.O.: MS 109 - REES, Albert Lloyd George. Can. J. Chem., 45(17), 1935-1948, 1967.

22. Mora S., Castro V. et al.: Chemical constituents from Zanthoxylum setulosum (Rutaceae). Bol. Latinoam. Caribe Plant. Med. Aromat., 10 (2), 155-158, 2011.

23. Musiol R., Magdziarz T., Kurczyk A.: Quinoline scaffold as a privileged substructure in antimicrobial drugs, Microbiology book series - No 3, Vol., 2011, 72-83.
24. Mwangi, E.S.K., Keriko, J. M. et al.: Antiprotozoal Activity and Cytotoxicity of metabolites from leaves of Teclea trichocarpa, J. Med. Plant. Res., 4(9), 726-731, 2010.

25. Peroutka, R., Schulzová, V., Botek, P., Hajšlová, J.: Analysis of furanocoumarins in vegetables (Apiaceae) and citrus fruits (Rutaceae), J. Sci. Food Agric., 87(11), 2152-2163, 2007.

26. Resmi M.S., Verma P., Gokhale R.S., Soniya E.V.: Identification and characterization of a Type III polyketide synthase involved in quinolone alkaloid biosynthesis from Aegle marmelos Correa, J. Biol. Chem., 288(10), 7271-7281, 2013.

27. Riyanto S., Sukari M.A. et al.: Alkaloids from Aegle marmelos (Rutaceae), Mal. J. Anal. Sci., 7(2), 463-465, 2001.

28. Sandjo L.P., Kuete V. et al.: Cytotoxic Benzophenanthridine and Furoquinoline Alkaloids from Zanthoxylum buesgenii (Rutaceae), Chem. Centr. J., 8(61), 4, 2014.

29. Sichaem J., Jirasirichote A. et al.: New furoquinoline alkaloids from the leaves of Evodia lepta, Fitoter., 92, 270-273, 2014.

30. Tavares L.C., Zanon G. et al.: Structure-Activity Relationship of Benzophenanthridine Alkaloids from Zanthoxylum rhoifolium Having Antimicrobial Activity. PLoS One, 9(5), 2014.

31. Tchinda A.T., Fuendjiepa V. et al.: Bioactive compounds from the fruits of Zanthoxylum leprieurii, Pharmacologyonline, 1, 406-415, 2009.

32. Touati D., Rahman A., Uluben A.: Alkaloids from Aegle marmelos (Rutaceae), Alkaloids from Ruta montana, Phytochem., 53, 277-279, 2000.

33. Vasudevan T.N., Lukner M.: Alkaloids from Ruta angustifolia, Ruta chalepensis and Ruta Montana. Pharmazie 23, 520-526, 1968.

34. Wahyunia T.S., Widyawaruyantib A. et al.: Inhibition of hepatitis $\mathrm{C}$ virus replication by chalepin and pseudane IX isolated from Ruta angustifolia leaves. Fitoterapia, 99, 276-283, 2014.

35. Wang L.D., Guo D.A. et al.: Antifungal effect of three natural products on the genetic substance of Saccharomyces cerevisiae GL7 and Prototheca wickerhamii. Yao Xue Xue Bao 35, 860-863, 2000.

36. Wansi J.D., Hussain H. et al.: Antiplasmodial activities of furoquinoline alkaloids from Teclea afzelii, Phytother. Res. 24, 775-777, 2010.

37. Wolski T., Baj T., The systematic of Dictamnus species and chemical composition of two cultivars of Dictamnus albus L.(cv. Albiflores and cv. Rosa purple). Part I, Post. Fitoter. 3, 166-179, 2014.

38. Wójcik G.: Wstępna ocena mrozoodporności wybranych gatunków z rodzaju Zanthoxylum L. [Rutaceae] w Ogrodzie Roślin Leczniczych we Wrocławiu, Rocznik dendrologiczny, 55, 159-164, 2007.

39. Zhao W., Wolfender J.L. et al.: Antifungal alkaloids and limonoid derivatives from Dictamnus dasycarpus. Phytochem. 47(1), 7-11, 1998.

40. Zhao Y.L., Chen Y.L., Chang F.S., Tzeng C.C.: Synthesis and cytotoxic evaluation of certain 4-anilino-2-phenylquinoline derivatives, Eur. J. Med. Chem. 40, 792-797, 2005. 